\title{
KONTRIBUSI PERAN GURU DALAM MENINGKATKAN KOMPETENSI SISWA DENGAN METODE BERTANYA DI SEKOLAH MENENGAH PERTAMA
}

\author{
Wawan Gunawan \\ Hari Karyono \\ Prodi Teknologi Pendidikan Pascasarjana UNIPA Surabaya \\ gunawan040485@yahoo.com \\ harikaryana@yahoo.com
}

\begin{abstract}
In learning rarely appear critical questions of the students, as a manifestation of their curiosity. Questions using question words: what, who, where, how, and why would produce different knowledge. Children who are critically marked with many questions. Clarity and complexity of what is being asked to indicate the ability of the child's thinking. Therefore, teachers should instead encourage, guide and train children to ask questions. Asking good questions is a good teaching.
\end{abstract}

Keywords: the role of teachers, increase competence, method of asking

\section{PENDAHULUAN}

Penyelenggaraan kegiatan belajar mengajar membutuhkan guru, yang berperan sebagai pembimbing, motivator, dan stimulator bagi anak-anak dalam upaya mengembangkan potensi dirinya. Anak perlu dibantu untuk mengembangkan potensi dirinya, dengan cara dibimbing, dimotivasi, dan diberi stimulus dengan berbagai pertanyaan agar potensi intelektualnya bisa berkembang secara optimal. Setiap anak dalam kodratnya adalah pembelajar yang cerdas. Setiap anak dianugrahi oleh Tuhan dengan rasa ingin tahu (curiosity), sebagai modal untuk mengembangkan intelektualnya. Setiap anak akan menanyakan segala sesuatu yang belum diketahui, dengan menggunakan kata tanya "apa" (what). Setelah mereka cukup memiliki pengetahuan, mereka akan bertanya dengan kata tanya bagaimana (how) dan mengapa (why).

Pembelajaran merupakan suatu proses yang kompleks dan melibatkan berbagai aspek yang saling berkaitan. Oleh karena itu, untuk menciptakan pembelajaran yang kreatif dan menyenangkan, diperlukan berbagai keterampilan. Diantaranya adalah keterampilan membelajarkan atau keterampilan mengajar.

Keterampilan mengajar merupakan kompetensi profesional yang cukup kompleks. Sebagai integrasi dari berbagai kompetensi guru secara utuh dan menyeluruh. Turney (1973) mengungkapkan 8 keterampilan mengajar yang sangat berperan dan menentukan kualitas pembelajaran, yaitu: (1) keterampilan bertanya, (2) memberi penguatan, (3) mengadakan variasi, (4) menjelaskan, (5) membuka dan menutup pelajaran, (6) membimbing diskusi kelompok kecil, (7) mengelola kelas, dan (8) mengajar kelompok kecil dan perorangan.

\section{PEMBAHASAN}

\section{Menggunakan Keterampilan Bertanya}

Keterampilan bertanya sangat perlu dikuasai oleh guru untuk menciptakan pembelajaran yang efektif dan menyenangkan, karena hampir dalam setiap tahap pembelajaran guru dituntut untuk mengajukan pertanyaan dan kualitas pertanyaan yang diajukan guru akan menentukan kualitas jawaban siswa.

Seperti yang diungkapkan Mulyasa (2005) bahwa keterampilan bertanya yang perlu dikuasai guru meliputi keterampilan bertanya dasar dan keterampilan bertanya lanjutan. Keterampilan bertanya dasar mencakup: (1) pertanyaan yang jelas dan singkat, (2) pemberian acuan, (3) pemusatan perhatian, (4) pemindahan giliran, (5) penyebaran pertanyaan ke seluruh kelas, ke siswa tertentu, dan ke 
siswa lain untuk menangggapi jawaban, (6) pemberian waktu berpikir, dan (7) pemberian tuntunan. Keterampilan bertanya lanjutan merupakan kelanjutan dari keterampilan bertanya dasar. Keterampilan bertanya lanjutan yang perlu dikuasai guru meliputi: (1) perubahan tuntunan tingkat kognitif, (2) pengaturan urutan bertanya, (3) pertanyaan pelacak, dan (4) peningkatan terjadinya interaksi.

Einstein pernah berujar, "Hal terpenting adalah tidak pernah berhenti berpikir". Saya jadi teringat satu kata, yaitu mengajar. Apa hubungan pernyataan Einstein dan mengajar? France (1859) seolah hendak menjawab pertanyaan penulis, "The whole art of teaching is only the art of awakening the natural curiosity of young minds for the purpose of satisfying it afterwards". Mengajar itu seni untuk merangsang keingin tahuan siswa. Rasa ingin tahu itulah sesungguhnya yang akan membuat siswa selalu ditantang untuk berpikir. Semua harus penuh tanda tanya, karena dengan itulah kita akan selalu berpikir. Mengapa kita harus berpikir? pasti saat ini Anda sedang berpikir. Jika tidak, maka Anda kurang punya rasa ingin tahu untuk mencari jawaban atas pertanyaan itu. Tegasnya, Anda enggan berpikir.

Menurut Kerry (1982), dalam waktu sepekan, guru kerap memberikan 1000 jenis pertanyaan dengan memiliki beragam tujuan, di antaranya untuk mendorong siswa berpartisipasi aktif di kelas, untuk memutuskan apakah siswa mengetahui atau tidak mengetahui sesuatu, untuk melibatkan siswa dalam aktivitas diskusi, untuk menarik perhatian siswa, untuk mengevaluasi tingkat pemahaman siswa, untuk menyediakan kesempatan mengulang materi pelajaran, dan untuk mengembangkan kemampuan berpikir kritis-kreatif siswa. Aneh rasanya jika ada guru lebih senang meminta siswa untuk duduk manis di bangku kelas. Duduk manis tak bisa menunjukkan ekspresi dan potensi siswa yang super unik. Tak ada pertanyaan, berarti tak belajar pula. Semua orang punya otak, tapi hanya sedikit orang yang menggunakan otaknya untuk berpikir. Optimalisasi otak lewat proses berpikir inilah yang mestinya menjadi menu utama dalam setiap kegiatan pembelajaran. Coba bayangkan sejenak, ketika kita hendak menutup pengajaran di kelas, tanyalah siswa-siswa Anda, "Apakah kalian sudah paham materi yang sudah disajikan?" Suasana kelas menjadi hening, tak ada satu pun siswa yang unjuk tangan. penulis coba bertanya lagi, "Adakah yang masih bingung dengan materi yang telah disajikan?" Semua siswa masih terdiam membisu. Sebagian besar siswa menghindari kontak mata dengan saya. Ini kisah nyata yang pernah penulis alami. Suasana kelas yang sudah telanjur terpenjara. Terpenjara oleh guru yang menutup semua pintu bagi siswanya untuk bertanya, berdiskusi, berdebat, $\&$ berpikir. Tak ada keleluasaan untuk melakukan itu semua. Mustahil siswa-siswi di kelas seperti ini punya kebebasan untuk berpikir $\&$ berjuang keras mencari jawaban atas semua keingintahuan mereka. Yang mengkhawatirkan, mereka akan jadi generasi pemalas. Malas berpikir \& berkreasi.

Kelas mestinya menjadi ruang ekspresi siswa yang dipenuhi suasana kemerdekaan. Merdeka untuk bertanya. Merdeka untuk menjawab pertanyaan. Merdeka untuk menyanggah jawaban. Merdeka untuk mengasah keterampilan berpikir. Kunci sukses terjadinya kemerdekaan di kelas terletak pada sosok guru yang open-minded dan punya keterampilan bertanya efektif.

\section{Prinsip-Prinsip Bertanya Efektif di Kelas}

Kita bisa mencermati beberapa anjuran terkait prinsip bertanya efektif di kelas dari McDaniel (2000) berikut: (1) buatlah rencana pertanyaan. Artinya, jangan merencanakan pertanyaan kepada murid bebera saat sebelum bertanya. Lebih baik semua pertanyaan itu termaktub di dalam RPP (lesson plan)yang kita buat, (2) gunakan beragam level jenis pertanyaan sehingga mampu memfasiltasi kemampuan berpikir tinggkat tinggi murid. Upayakan semua pertanyaan mengikuti kaidah M-S dan S-R (mudah-sukar dan sederhanarumit), (3) sediakan waktu jeda kepada murid untuk menjawab pertanyaan, (4) menahan diri untuk tidak segera memberikan opini terhadap 
jawaban murid pada jenis pertanyaan yang menuntut kemampuan berpikir tinggi. Hindari kebiasaan untuk segera menanggapi jawaban murid. Berikan kesempatan kepada murid untuk saling mendengarkan jawaban di antara mereka, (5) jangan bermain aman. Maksudnya, jangan berikan pertanyaan yang kita sendiri sebagai guru sudah tahu jawabannya. Berikanlah pertanyaan yang kita sendiri juga belum tahu jawaba pastinya, (6) dengarkan secara seksama setiap jawaban murid, (7) berikan penguatan positif atas jawaban murid, (8) gunakan teknik bervariasi dalam meminta murid menjawab pertanyaan. Misalnya dengan mengambil kartu yang sudah berisi nama-nama murid secara acak, (9) ajarkan kepada murid bagaimana cara menjawab pertanyaan, dan (10) ajarkan juga kepada murid bagaimana cara membuat pertanyaan.

\section{Peran Guru}

Semua orang yakin bahwa gurulah yang memiliki andil yang sangat besar terhadap keberhasilan pembelajaran di sekolah. Guru sangat berperan dalam membantu perkembangan siswa untuk mewujudkan tujuan hidupnya secara optimal. Mulyasa (2005) mengemukakan bahwa guru harus kreatif, profesional, dan menyenangkan dengan memposisikan diri sebagai berikut: (1) orang tua yang penuh kasih sayang pada siswanya, (2) teman, tempat mengadu dan mengutarakan perasaan bagi para siswanya, (3) fasilitator yang selalu siap memberikan kemudahan dan melayani siswa sesuai minat, kemampuan, dan bakat, (4) memberikan sumbangan pemikiran kepada orang tua untuk dapat mengetahui permasalahan yang dihadapi siswa dan memberikan saran pemecahanya, (5) memupuk rasa percaya diri, berani dan bertanggung jawab, (6) membiasakan siswa untuk saling bersilaturahmi dengan orang lain secara wajar, (7) mengembangkan proses sosialisasi yang wajar antar siswa, orang lain dan lingkungan, (8) mengembangkan aktivitas, dan (9) menjadi pembantu ketika diperlukan.

Untuk memenuhi tuntutan diatas, guru harus mampu memaknai pembelajaran, serta menjadikan pembelajaran sebagai ajang pembentukkan kompetensi dan perbaikan kualitas pribadi siswa. Untuk kepentingan tersebut, dengan memperhatikan kajian dalam buku Mulyasa (2005) bahwa Pullis dan Young (1988), Manan (1990) serta Yelon and Weinstien (1997) dapat diidentifikasikan sedikitnya peran guru: (1) guru sebagai pendidik, (2) pengajar, (3) pembimbing, (4) pelatih,

penasehat,

pembaharu/innovator, (7) model dan teladan, (8) pribadi, (9) peneliti, (10) pendorong kreativitas, (11) pembangkit pandangan, (12) pekerja rutin, (13) pemindah kemah, (14) pembawa cerita, (15) aktor, (16) emansipator, (17) evaluator, (18) pengawet, dan (19) kulminator.

Seperti yang diungkapkan Purwanto (2006) bahwa prestasi belajar tergantung pada faktor yang berasal dari dalam diri individu itu sendiri yang meliputi kondisi fisik, kondisi panca indera, bakat, minat, kecerdasan, motivasi, kemampuan kognitif, dan faktor yang berasal dari luar individu yang sering diseebut sebagai faktor sosial itu seperti alam, kurikulum, lingkungan, guru, sarana dan fasilitas dan administrasi.

Sedangkan Undang-Undang Republik Indonesia Nomor 14 Tahun 2005 tentang Guru dan Dosen, dijelaskan bahwa kompetensi adalah seperangkat pengetahuan, keterampilan dan perilaku yang dimiliki, dihayati, dan dikuasai oleh guru atau dosen dalam melaksanakan tugas keprofesionalan. Guru merupakan ujung tombak yang berhubungan lansung dengan siswa sebagai subjek dan objek belajar. Sebab inti dari kegiatan pendidikan adalah belajar mengajar yang memerlukan peran guru di dalamnya. Oleh karena itu guru dituntut untuk profesional dalam pekerjaan.

Menurut Usman (2010) guru merupakan jabatan atau profesi yang memerlukan keahlian khusus sebagai guru. Pekerjaan sebagai guru tidak dapat dilakukan oleh sembarang orang diluar bidang pendidikan walaupun dalam kenyataannya masih banyak profesi guru dari luar pendidikan.

Keutamaan profesi guru tersebut secara implisit dan eksplisit juga diperlihatkan dalam 
kehidupan masyarakat. Guru adalah suatu pekerjaan yang mulia. Jika para guru melakukan tugasnya secara ikhlas dan disertai niat hanya karena Allah, maka mereka sudah memiliki "tiket masuk surga", karena ilmu yang diberikan akan menjadi amal sholeh. Bahkan jika para guru dalam mendidik siswanya dilandasi dengan kasih sayang, maka mereka juga akan mendapat tambahan bonus dicintai oleh siswanya. Oleh karena itu, guru yang baik akan memperoleh tiga gaji, yaitu gaji dari pemerintah atau yayasan berupa uang, gaji dari Allah berupa pahala, dan gaji dari mantan siswa-siswanya, paling tidak berupa doa.

Mungkin semua orang masih ingat, ketika kota Hirosimma dan Nagasaki dijatuhi bom atom oleh tentara sekutu pada tanggal 6 dan 9 Agustus 1945, yang menewaskan ratusan ribu penduduk kedua kota tersebut, pertanyaan yang dilontar oleh Kaisar Hirohito, bukan berapa tentara yang masih hidup, tetapi berapa jumlah guru yang tersisa. Pertanyaan Kaisar Hirohito tersebut, menunjukan guru memiliki peran yang sangat penting bagi bangsa dan Negara serta posisi yang terhormat di masyarakat. Di sisi lain juga menujukan bahwa Beliau memiliki pandangan yang jauh ke depan, dan memahami betapa pentingnya pendidikan bagi suatu bangsa, dan guru merupakan aktor utama dalam pendidikan. Pentingnya pendidikan ini juga disampaikan oleh Lyndon B Johson Presiden Amerika Serikat periode (1963-1969) bahwa all the problem can be solved with one word is education.

Semenjak dikeluarkan Undang-undang Nomor 14 Tahun 2005 tentang Guru dan Dosen harus memiliki prinsip-prinsip profesional seperti tercantum pada pasal 5 ayat 1, yaitu: profesi guru dan dosen merupakan bidang pekerjaan khusus yang memerlukan prinsip-prinsip profesional sebagai berikut: (1) memiliki bakat, minat, panggilan jiwa dan idealisme, (2) memiliki kualifikasi pendidikan dan latar belakang pendidikan sesuai dengan bidang tugasnya, (3) ) memiliki kompetensi, (4) mematuhi kode etik profesi, (5) memiliki hak dan kewajiban dalam melaksanakan tugas, (6) memperoleh penghasilan yang ditentukan sesuai dengan prestasi kerjanya, (7) memiliki kesempatan untuk mengembangkan profesinya secara berkelanjutan, (8) memperoleh lindungan hukum dalam melaksanakan tugas profesionalnya, dan (9) memiliki organisasi profesi yang berbadan hukum.

Peran guru sebagai penggugah kesadaran kritis ini sejalan dengan Kurikulum 2013, yang ingin mengembangkan kemampuan berpikir tingkat tinggi siswa. Melalui pendekatan keilmuan (scientific approach), para guru harus mengajar, membimbing, dan melatih siswa untuk membangun kemampuan berpikir krits, dengan bertanya. Dalam setiap pembelajaran, siswa harus dilatih melakukan pengamatan, menyusun pertanyaan terhadap apa yang diamati, menggumpulkan data, menganalis data, dan kemudian mengambil kesimpulan, serta menyebarkan hasilnya. Dengan pendekatan keilmuan dalam proses belajar mengajar diharapkan dapat menghasilkan orang-orang yang mampu berpikir tingkat inggi, yang pada gilirannya bisa memcahkan masalah.

\section{Metode Bertanya}

Metode bertanya merupakan salah satu metode pembelajaran tertua yang digunakan untuk mengajar. Menurut Mulyasa (2007), metode bertanya merupakan cara menyajikan bahan ajar dalam bentuk pertanyaanpertanyaan yang memerlukan jawaban untuk mencapai tujuan. Pertanyaan ini bisa muncul dari guru maupun dari siswa. Pertanyaan dapat merangsang aktivitas dan kreativitas berpikir siswa.

Metode bertanya adalah metode mengajar yang memungkinkan terjadinya komunikasi lansung yang bersifat dua arah sebab pada saat yang sama terjadi dialog antara guru dan siswa. Guru bertanya siswa menjawab dalam komunikasi itu terlibat adanya hubungan timbal balik secara lansung antara guru dengan siswa, Ibrahim (2003).

Hasibuan \& Moedjiono (2008) berpendapat, dalam proses belajar mengajar, bertanya memegang peranan yang penting sebab pertanyaan yang tersusun baik dengan 
teknik pengajuan yang tepat, akan: (1) meningkatkan partisipasi siswa dalam kegiatan dalam belajar mengajar, (2) meningkatkan minat dan rasa ingin tau siswa terhadap masalah yang sedang dibicarakan, (3) mengembangkan pola berpikir dan belajar aktif siswa, sebab berpikir itu sendiri adalah bertanya, (4) menuntun proses berpikir siswa, sebab pertanyaan yang baik akan membantu siswa agar dapat menentukan jawaban yang baik, dan (5) memusatkan perhatian siswa terhadap masalah yang sedang dibahas.

Keterampilan dasar mengajar bertanya adalah suatu aktifitas guru yang berupa ungkapan pertanyaan kepada anak didik untuk menciptakan pengetahuan dan meningkatkan kemampuan berfikir. Fungsi pertanyaan dalam kegiatan pembelajaran sepintas telah disinggung dalam bagian rasional, dan menurut Turney (1973) mengidentifikasi 12 fungsi pertanyaan seperti berikut: (1) membangkitkan minat dan keingintahuan siswa tentang suatu topik, (2) Memusatkan perhatian pada masalah tertentu, (3) menggalakkan penerapan belajar aktif, (4) merangsang siswa mengajukan pertanyaan sendiri, (5) menstrukturkan tugas-tugas hingga kegiatan belajar dapat berlangsung secara maksimal, (6) mendiagnosis kesulitan belajar siswa, (7) mengkomunikasikan dan merealisasikan bahwa semua siswa harus terlibat secara aktif dalam pembelajaran, (8) menyediakan kesempatan bagi siswa untuk mendemostrasikan pemahamannya tentang informasi yang diberikan, (9) melibatkan siswa dalam memanfaatkan kesimpulan yang mendorong mengembangkan proses berpikir, (10) mengembangkan kebiasaan menanggapi pernyataan teman atau pernyataan gurunya, (11) memberikan kesempatan untuk belajar berdiskusi, dan (12) menyatakan perasaan dan pikiran yang murni kepada siswa.

\section{Menurut Djamarah}

(2006)

mengemukakan bahwa, metode bertanya adalah cara menyajikan pelajaran dalam bentuk pertanyaan yang harus dijawab, terutama dari guru kepada siswa dan dari siswa ke guru. Metode tanya jawab adalah metode tertua dan banyak digunakan di dalam pendidikan, baik di lingkungan keluarga, masyarakat maupun di sekolah. Selanjutnya Roestiyah (2001) juga berpendapat, untuk menciptakan kehidupan interaksi belajar mengajar perlu guru menimbulkan teknik bertanya atau berdialog, ialah suatu tehnik untuk memberikan motivasi pada siswa agar bangkit pemikirannya untuk bertanya, selama mendengarkan pelajaran atau guru mengajukan pertanyaan-pertanyaan.

Dari beberapa pendapat para pakar pendidikan tersebut dapat diketahui bahwa metode pembelajaran bertanya pada intinya adalah cara penyajian materi pelajaran dalam proses belajar mengajar yang bertujuan proses belajar siswa dalam bentuk pertanyaanpertanyaan yang telah disiapkan terlebih dahulu oleh guru kepada siswa maupun dari siswa kepada guru.

\section{Tujuan Penerapan Metode Bertanya}

Mengenai tujuan yang akan dicapai dalam metode bertanya, Yamin (2006) menyatakan metode pembelajaran bertanya dapat dinilai sebagai metode yang tepat, apabila pelaksaannya ditunjukkan untuk: (1) meninjau ulang pelajaran atau ceramah yang lalu, agar siswa memusatkan lagi perhatiannya pada jenis dan jumlah kemajuan yang telah dicapai sehingga mereka dapat melanjutkan pelajrannya, (2) menyelingi pembicaraan agar tetap mendapat perhatian siswa, dan (3) mengarahkan pengamatan dan pemikiran mereka.

Menurut Roestiyah (2001) guru melontarkan teknik tanya jawab itu mempunyai tujuan: (1) agar siswa dapat mengerti atau mengingat-ingat tentang fakta yang dipelajari, didengar ataupun dibaca, sehingga mereka memiliki pengertian yang mendalam tentang materi itu, (2) diharapkan pula dengan bertanya itu mampu menjelaskan langkah-langkah berpikir atau proses yang ditempuh dalam memecahkan masalah, sehingga jalan pemikiran anak tidak meloncat-loncat yang akan merugikan siswa itu sendiri dalam menangkap suatu masalah, (3) penggunaan tehnik bertanya biasanya baik 
untuk maksud-maksud yang diperlukan untuk menyimpulkan atau mengiktisarkan pelajaran atau apa saja yang dibaca, dengan dibantu metode bertanya siswa akan tersusun jalan pikirannya sehingga mencapai perumusan yang baik dan tepat, (4) dapat membantu tumbuhnya perhatian siswa pada pelajaran, serta mengembangkan kemampuannya untuk menggunakan pengetahuan dan pengalamannya, sehingga pengetahuannya menjadi berfungsi, (5) dalam tanya jawab itu pula guru bermaksud meneliti kemampuan/daya tangkap siswa untuk dapat memahami bacaan, agar mereka paham apa yang sedang dibaca, dan (6) dapat mengetahui juga apakah siswa dapat mendengar dengan baik.

\section{Kebaikan dan Kelemahan Metode Bertanya \\ Penggunaan metode bertanya} memiliki beberapa kebaikan menurut Roestiyah (2001) dalam pelaksanaannya teknik ini ada keunggulannya seperti kelasakan lebih hidup, karena sambutan kelas lebih baik siswa tidak hanya mendengarkan ceramah saja. Dengan bertanya partisipasi siswa lebih besar dan berusaha mendengarkan pertanyaan guru dengan baik dan mencoba untuk memberikan jawaban yang tepat, sehingga anak menerima dengan aktif berpikir, tidak pasif mendengarkan saja.

Kebaikan metode bertanya menurut Yamin (2006) menyatakan bahwa: (1) bertanya dapat memproleh sambutan yang lebih aktif bila dibandingkan dengan metode ceramah yang bersifat monolog, (2) memberikan kesempatan kepada siswa untuk mengemukakan pendapat sehingga nampak mana yang belum jelas atau belum mengerti, dan (3) mengetahui perbedaan-perbedaan pendapat yang ada yang dapat dibawa ke arah diskusi.

Djamarah (2006) juga mengemukakan kelebihan metode tanya jawab: (1) pertanyaan dapat menarik dan memusatkan perhatian siswa, (2) meransang siswa untuk melatih dan mengembangkan daya pikir termasuk daya ingat, dan (3) mengembangkan keberanian dan keterampilan siswa dalam menjawab dan mengemukan pendapat.

Kelemahannya adalah bahwa bertanya bisa menimbulkan penyimpangan dari pokok persoalan. Jika kelompok siswa memberikan jawaban atau mengajukan pertanyaan yang dapat menimbulkan masalah baru dan menyimpang dari pokok permasalahan.

Kekurangan metode bertanya: (1) siswa merasa takut, apalagi bila guru kurang dapat mendorong siswa untuk berani, (2) tidak mudah membuat pertanyaan yang sesuai dengan tingkat berpikir dan mudah dipahami, (3) waktu sering banyak terutama apabila siswa tidak dapat menjawab pertanyaan, (4) dan dalam jumlah siswa yang banyak tidak mungkin cukup waktu untuk memberikan pertanyaan kepada setiap siswa

\section{Jenis-Jenis Pertanyaan}

Menurut Sanjaya (2005) dalam melakukan pertanyaan akan sangat penting untuk mengetahui jenis-jenis pertanyaan sebagai berikut: (1) pertanyaan pengetahuan, yang menuntut siswa untuk mengingat dan mengatakan kembali fakta-fakta yang telah dipelajari. Kata- kata yang biasanya digunakan untuk membuat pertanyaan pengetahuan adalah. Siapa, apa, dimana, dan bilamana. Contohnya: Apa nama ibu kota propinsi jawa timur?, (2) pertanyaan yang mengandung unsur suruhan, dengan harapan agar siswa dapat mematuhi perintah yang diucapkan, oleh karena itu pertanyaan ini tidak mengharapkan jawaban dari siswa, akan tetapi yang diharapkan tindakan siswa. Contoh: dapatkah kamu menunjukan batas-batas wilayah propinsi jawa timur pada peta yang ada didepan kamu?, (3) pertanyaan pemahaman, suatu bahan yang telah dipelajari yang terlihat antara lain dalam kemampuan seseorang menafsirkan informasi. Contoh: jelaskan menurut kata- katamu sendiri tentang proses pembuatan brownis?, (4) pertanyaan penerapan, pertanyaan yang menuntut anak untuk memberi jawaban tunggal yang benar dengan cara menerapkan pengetahuan, informasi, rumus-rumus, untuk memecahkan persoalan-persoalan baru. 
contohnya, Berilah contoh pengamalan sila ke IV Pancasila?, (5) pertanyaan analisa, merupakan suatu pertanyaan yang menuntut anak untuk berfikir lebih kritis yang dalam dengan suatu jalan penyelesaian. Contohnya: kehidupan di desa lebih tenang dibandingkan dengan kehidupan dikota, dapatkah anda mencari bukti-bukti?, (6) pertanyaan sintesa, pertanyaan yang menuntut anak untuk mengembangkan daya kreasinya, dan cirinya adalah bahwa jawaban yang benar tidak satu. Contohnya: Apa yang terjadi apabila hutan terus ditebangi?, dan (7) pertanyaan evaluasi, pertanyaan yang menghendaki jawaban siswa dengan cara memberi penilaian atau pandangannya terhadap suatu peristiwa atau suatu kejadian. Contohnya: bagaimana pendapatmu tentang kenakalan remaja akhirakhir

Tabel 1. Jenis pertanyaan yang bisa disiasati oleh guru ketika melakukan pembelajaran

\begin{tabular}{|l|l|l|}
\hline \multicolumn{1}{|c|}{ Katagori Pertanyaan } & \multicolumn{1}{|c|}{ Arti } & \multicolumn{1}{c|}{ Contoh } \\
\hline Terbuka & $\begin{array}{l}\text { Pertanyaan yang memiliki } \\
\text { lebih dari satu jawaban } \\
\text { benar. }\end{array}$ & $\begin{array}{l}\text { Mengapa ibu kota Indonesia, } \\
\text { Jakarta? }\end{array}$ \\
\hline Tertutup & $\begin{array}{l}\text { Pertanyaan yang memiliki } \\
\text { hanya satu jawaban yang } \\
\text { benar. }\end{array}$ & $\begin{array}{l}\text { Apa nama ibu kota } \\
\text { Indonesia? }\end{array}$ \\
\hline Produktif & $\begin{array}{l}\text { Dapat dijawab melalui } \\
\text { pengamatan, percobaan, } \\
\text { penyelidikan. }\end{array}$ & $\begin{array}{l}\text { Berapa halam kertas } \\
\text { diperlukan untuk } \\
\text { menghabiskan sebuah spidol } \\
\text { ini? }\end{array}$ \\
\hline Tidak produktif & $\begin{array}{l}\text { Dapat dijawab hanya dengan } \\
\text { melihat, tampa melakukan } \\
\text { pengamatan, percobaan, atau } \\
\text { penyelidikan. }\end{array}$ & Apa benda ini? \\
\hline Imajinatif/interpretatif & $\begin{array}{l}\text { Jawabnya diluar benda } \\
\text { gambar/ kejadian yang } \\
\text { diamati. }\end{array}$ & $\begin{array}{l}\text { "gambar gadis termenung di } \\
\text { pinggir laut". Apa yang } \\
\text { sedang dipikirkan gadis itu? }\end{array}$ \\
\hline
\end{tabular}

Sumber: Masnur (2007)

\section{Etika Bertanya Diruang Diskusi}

Di dalam rapat, seminar atau di dalam kelas kita sering melihat pejabat, dan siswa mengajukan pertanyaan yang kurang sopan. Seperti halnya juga rapat anggota dewan yang sering ribut dalam mengajukan pertanyaan. Charlian (2012) memberikan etika bertanya di ruangan diskusi: (1) tunjukkan tangan ketika anda mau bertanya, (2) sebaiknya anda berdiri ketika menyampaikan pertanyaan, (3) ucapkan salam pembuka dengan singkat, (4) sebutkan identitas anda, (5) bertanya dgn to the point/tidak bertele-tele \& berputar-putar, lebih banyak bumbunya daripada pertanyaanya, (6) sebutkan jumlah pertanyaan anda dengan jelas,
(7) jangan bertanya terlalu banyak, maksimal 3 buah pertanyaan, (8) Tujukan pertanyaan itu kepada siapa dan dalam bidang apa, (9) suara tidak pelan, tapi keras, jelas, tegas, dan dimengerti, (10) pertanyaan jangan bersifat menjebak, mengetest, menghina, melecehkan, atau menasehati, menggurui dll. (11) hindari penggunaan istilah bahasa asing yang berlebihan, (12) jangan memotong jawaban pembicara atau guru sebelum selesai menjelaskan, (13) perhatikan jawaban pertanyaan anda ketika guru atau pembicara menjawab, (14) jangan bersikap acuh tak acuh/bermain hp, ngobrol ketika pembicara menjawab, (15) ajukan pertanyaan yang 
memang memerlukan pemecahan masalah, jangan mengajukan pertanyaan yang tidak perlu, (16) bila perlu tulis dulu pertanyaan anda sehingga anda tidak salah menyampaikan, dan (17) usahakan jangan bertanya keluar dari fokus permasalahan yang dibahas

\section{REKOMENDASI}

Bertanya merupakan ucapan verbal yang meminta respons dari orang yang dikenai. Respons yang diberikan dapat berupa pengetahuan sampai dengan hal-hal yang merupakan stimulus efektif yang mendorong kemampuan berpikir. Mendefenisikan pertanyaan adalah segala pernyataan yang menginginkan tanggapan verbal. Pertanyaan tidak selalu dalam bentuk tanya, tetapi dapat juga dalam bentuk kalimat perintah. Bertanya adalah setiap pernyataan yang mengkaji atau menciptakan ilmu pada diri siswa. Cara untuk mengajukan pertanyaan yang berpengaruh positif bagi kegiatan belajar siswa merupakan suatu hal yang tidak mudah. Oleh sebab itu, sebagai guru kita hendaknya berusaha agar memahami dan menguasai penggunaan keterampilan dasar bertanya. Keterampilan bertanya sangat perlu dikuasai oleh guru untuk menciptakan pembelajaran yang efektif dan menyenangkan, karena hampir dalam setiap tahap pembelajaran guru dituntut untuk mengajukan pertanyaan dan kualitas pertanyaan yang diajukan guru akan menentukan kualitas jawaban siswa

\section{SIMPULAN DAN SARAN}

\section{Simpulan}

Keterampilan dasar bertanya mengandung dua unsur penting: Pertanyaan dasar dan Pertanyaan lanjutan. Dalam melemparkan sebuah pertanyaan, seorang guru itu harus ada acuan, antara lain: memberikan pertanyaan jelas dan singkat, ada acuan yang berfungsi perhatian, pemberian giliran dengan cara memberikan pertanyaan secara bergiliran dan tuntunan, pertanyaan melacak dan pengubahan tuntunan tingkat kognitif.

Keterampilan yang diperlukan oleh seorang guru; menguasai materi dan menguasai metodologinya. Keterampilan bertanya bertujuan untuk menumbuhkan motivasi, menumbuhkan minat belajar, memusatkan perhatian, melatih keterampilan berfikir dan mengkondisikan belajar. Pemberian tuntunan harus mendasar pada acuan ini: perintahnya harus dengan kalimat sederhana dan ada contoh. Hal-hal yang tidak boleh dilakukan oleh guru, antara lain: memancing jawaban serentak, bertanya langsung dan berurutan, mengulangi jawab siswa, mengulangi pertanyaan sendiri, menyebut nama sebelum bertanya dan mengajukan pertanyaan benda.

\section{Saran}

proses bebaiknya guru mencapai tujuan dari membangkitkan minat dan rasa ingin tahu terhadap pokok bahasan, (2) memusatkan perhatian, (3) mendiagnosis kegiatan khusus yang menghambat siswa belajar, dan (4) mengembangkan SCL (Student Center Learning).

Guru juga harus memperhatikan hal-hal kebiasaan yang harus dihindari sebagai berikut: (1) mengulangi pertanyaan sendiri, (2) pertanyaan ganda, (3) pertanyaan yang memancing jawaban serentak, (4) mengulangi jawaban siswa, (5) menjawab pertanyaan sendiri (6) menentukan siswa tertentu untuk menjawabnya, dan (7) akibatnya anak yang tidak ditunjuk tidak memikirkan jawabanya.

\section{Daftar Rujukan}

Alma, B. 2008. Guru Professional. Bandung: Alfabeta.

Charlian, A. 2012. Etika Bertanya di Dalam Kelas. Summary of Citing Internet Sites. Disscussion List, (Online), (www.antoncharlian.com), diakes 8 Maret 2015.

Djamarah, S.B. \& Zain, A. 2006. Strategi Belajar Mengajar. Jakarta: Rineka Cipta. 
Tahun XI, No. 20, April 2015

Hasibuan \& Moedjiono. 2008. Proses Belajar Mengajar, Bandung: Remaja Rosdakarya.

Ibrahim. 2003. Proses Belajar Mengajar. Bandung: Remaja Rosdakarya.

Kerry. 1982. Ability Groupping in Education. London: Paul Chapman.

Masnur, M. 2007. Kurikulum Tingkat Satuan Pendidikan. Jakarta: Bumi Aksara.

McDaniel,T.R. 2000. How to Question Effectively. Jurnal Teaching For Excellence, (Online), (Https://www.teachingforexcellence.c om) diakses 08 Maret 2015.

Mulyasa, E. 2005. Menjadi Guru, Menciptakan Pelajaran Kreatif dan Menyenangkan. Bandung: Remaja Rosdakarya.

Mulyasa, E. 2007. Menjadi Guru Profesional. Bandung: Remaja Rosdakarya.

Ngalim, P. 2006. Psikologi Pendidikkan. Bandung: Remaja Rosdakarya.

Roestiyah. 2001. Strategi Belajar Mengajar. Jakarta: Rineka Cipta.

Sanjaya, W. 2005. Pembelajaran dalam Inflementasi Kurikulum Berbasis Kompetensi. Bandung: Kencana Prenada.

Schunk, D. H. 2004. Learning Theories an Educational Perspective. Upper Saddle River: Pearson Prentice Hall.

Sukirman, D \& Mamad K. 2006. Pembelajaran Micro. Bandung: UPI Press.

Turney, C. 1973. Reinforcement Basic Questioning Variability Handbook. Sydney: Sydney University Press.

Undang-Undang Republik Indonesia Nomor 14 Tahun 2005 tentang Guru dan Dosen.
Usman, M.U. 2010. Menjadi Guru Profesional. Bandung: Remaja Rosdakarya.

Winataputra, U.S. 2002. Strategi Belajar Mengajar. Jakarta: UT.

Yamin, H.M. 2007. Profesional Guru dan Implementasi KTSP. Jakarta: Gaung Persada Press. 
Tahun XI, No. 20, April 2015 